\title{
Reflexión sobre la reforma del Estado
}

\author{
Marc Tarrés Vives \\ Profesor agregado de Derecho Administrativo. Universidad de Barcelona \\ marc.tarres@ub.edu
}

Que el momento presente se ofrece lleno de interrogantes, y más aún en nuestro país, es algo que no escapa a ninguno de los participantes en este Seminario sobre la reforma del Estado, nacido con buen tino bajo el auspicio del Profesor Santiago Muñoz Machado. Son tiempos de turbación y si bien la máxima ignaciana nos instaría a evitar toda mudanza, lo cierto es que el consejo del de Loyola en realidad nos advierte contra la toma de decisiones "en caliente" cuando se trata de dirimir asuntos de trascendencia. En otras palabras, no recomienda la inacción, sino la búsqueda de la serenidad necesaria para adoptar aquellas decisiones que mejor puedan ayudar a superar momentos de cambio y conducir de la manera más apropiada hacia nuevos escenarios. Y no cabe duda que la crisis, o conjunción de diferentes crisis, nos lleva a escenarios diferentes a los vividos en estos últimas décadas.

En las ponencias ha quedado claramente puesto de manifiesto que los cambios son de distinto orden y distinguibles, si bien en unos casos ofrecen contornos más definidos que en otros. En este sentido, el crack financiero ocurrido en 2008 desencadenó un cambio de tendencia en la visión idílica de los mercados y en el papel que los Estados y determinadas organizaciones supranacionales debían tener respecto aquéllos. Ese es un cambio que ha ido operando de un modo perceptible a través de una mayor regulación, que no resulta exclusivamente de naturaleza jurídica, y una menor confianza en las fórmulas de la autorregulación tan en boga hasta ese momento. Siguiendo a Agamben, el paradigma del mercado autorregulado habría fingido la posibilidad de gobernar un sociedad cada vez más compleja prescindiendo de la justicia y del derecho y según criterios exclusivamente técnicos. Por fortuna parece que hemos advertido el error.

Paradójicamente, sin embargo, hay que reconocer que el trazado de esos nuevos caminos regulatorios viene en gran medida diseñado por procedimientos y formalidades procedentes del ámbito empresarial, o si se prefiere de la sociedad. Y ello es así por cuanto el Estado ha terminado por mostrar una desnudez extrema e inimaginable para unos ciudadanos que han tomado, y no sin motivo, sus prestaciones como auténticos derechos.

Por este motivo, la crisis en lo económico ha revelado una crisis político institucional en numerosos países y de manera especial en España. Aspectos clave como legalidad y legitimidad, o el cómo se articula la relación entre Estado y sociedad han emergido nuevamente con una virulencia extrema y con la necesidad de acudir a nuevas formulaciones acordes con el momento actual. $Y$ por supuesto, todo ello adquiriendo una relevancia constitucional. En el caso español la impuesta reforma constitucional del artículo 135 supone algo más que consagrar la estabilidad presupuestaria, supone reconocer la condición del Estado "deudor" y que el mantenimiento de su aparato administrativo se liga de modo incondicionado a limitar el gasto con el fin de pagar lo que se debe. Ya no caben incumplimientos en los compromisos de pago de la deuda pública, o en otras palabras la posibilidad de tal decisión está descartada habiendo sido sustraída a los representantes de la soberanía nacional. Pero la afección a la Constitución no viene solo de esa modificación precipitada y absolutamente carente de un mínimo debate político, procede también de una nueva realidad político-social que no afectando, por el momento, a sus formas textuales sí, en cambio, está en proceso de transmutar su contenido. Y eso supone, por supuesto, una crisis de calado que debe ser también afrontada mediante una modificación de la Constitución llevada a cabo sin complejos y mediante acciones voluntarias e intencionadas, tal como escribiera Jellinek.

Por último nos interesa subrayar, en línea con lo expuesto en su ponencia por el Profesor Esteve Pardo, la importancia de esa nueva correlación entre Estado y sociedad. En ella hay que atender a cual debe ser el papel que 
le corresponde desempeñar a la Administración y para ello hay que atender a una nueva formulación del Estado. La de Estado garante es una adjetivación que se corresponde con aquello que el Estado puede hacer y lo que mínimamente se puede esperar de él. No podemos ser llevados de la mano por el Estado pero tampoco podemos prescindir de su compañía. El Estado ya no proveerá directamente pero sí nos acompañará a modo de un constante proceso de cooperación con cada individuo en aras de lograr su desarrollo como ciudadano. Se trata de algo más que la mera prestación material, es garantizar la existencia de cada persona en la máxima autonomía posible. 